Katarzyna Salamon

(D) https://orcid.org/0000-0003-0601-9442

Uniwersytet Papieski Jana Pawła II w Krakowie

\title{
Tożsamość społeczna jako fakt interakcyjny
}

doi https://doi.org/10.15633/9788374389839.02

Głównym celem niniejszego opracowania jest analiza etycznego/relacyjnego aspektu tożsamości społecznej. Relacyjność wynika z pojmowania tożsamości społecznej jako procesu zachodzącego pomiędzy makro-i mezorostrukturą a poszczególnymi jednostkami.

Odwołując się do konstrukcjonizmu społecznego, założono, iż tożsamość jest faktem interakcyjnym stale interpretowanym - powstaje w wyniku interakcji i interpretacji oraz za ich pośrednictwem się realizuje. Wydaje się również faktem wciąż niedopełnionym, stającym się, wyłaniającym, poszukującym swego miejsca w świecie społecznym.

Tożsamość jest zatem stale tworzona, stanowi subiektywny element rzeczywistości (jest tożsamością określonej jednostki), ale pozostający ze społeczeństwem w dialektycznym związku (nie ma tożsamości społecznej poza określonym kontekstem kulturowym) ${ }^{1}$. Jako fakt społeczny jest ona kształtowana przez trzy główne czynniki:

- procesy;

- strukturę;

- społeczną oraz normatywną i symboliczną warstwę kultury.

Świat społeczny obfituje w przykłady procesów kształtowania się tożsamości społecznej. W niniejszym opracowaniu analizie poddano „nową tożsamość społeczną” pracowników socjalnych. Praca socjalna zmienia się na naszych oczach, zyskuje nowe właściwości, a rezultatem tego jest kluczowy proces powstawania „nowej tożsamości” pracowników socjalnych. Wielorakość problemów społecznych, gwałtownie rozwijające się oraz

$1 \quad$ P. Berger, T. Luckmann, Społeczne tworzenie rzeczywistości, Biblioteka Myśli Współczesnej, Warszawa 1983, s. 262. 
profesjonalizujące środowiska pracowników socjalnych z jednej strony oraz teoretyczne i akademickie podstawy tej przekształcającej się profesji z drugiej - tworzą dla kształtowania się ich tożsamości społecznej swoiste i interesujące ramy. Proces ten wymaga ciągłych, wielowymiarowych interpretacji.

\section{Między tożsamością indywidualną a społeczną}

W refleksji nad tożsamością często występuje dychotomia: tożsamość indywidualna (jednostkowa, osobista) i kolektywna (społeczna, zbiorowa).

Tożsamość osobista (indywidualna) to świadomość siebie, która jest jednocześnie świadomością innych - oczekiwań, jakie z nami wiążą, i odpowiedzialności, jaka z nich wynika. Aby jednostka mogła wytworzyć tożsamość osobową w relacjach $\mathrm{z}$ innymi, musi funkcjonować $\mathrm{z}$ nimi we wspólnym „symbolicznym świecie sensów”. Kluczowym słowem, które wydaje się opisywać relację pomiędzy ludźmi, jest „wobec”. Słówko „wobec" to podstawowe określenie stosunku człowieka do człowieka, a szerzej rzecz ujmując, bytu świadomego do bytu świadomego. Być wobec to nie to samo co być obok albo w pobliżu. Znaczenie słowa „wobec” domaga się wzajemności: patrzę na ciebie i jestem widziany, troszczę się i jestem przedmiotem troski, myślę o kimś i ktoś o mnie myśli. Tożsamość jednostki kształtuje się w określonej grupie pod wpływem określonej kultury i jest jedyną możliwością tworzenia obrazu samego siebie, koncepcji siebie czy identyfikowania się $e^{2}$ Tożsamość jednostkowa i społeczna dotyczą różnych poziomów życia człowieka, lecz są ze sobą ściśle związane. Jak zauważa Jerzy Nikitrowicz, o ile tożsamość osobista zakotwiczona jest w potrzebie unikatowości, o tyle tożsamość społeczna zasadza się na potrzebie przynależności i podobieństwa do innych ${ }^{3}$. „Tożsamości społeczne określają, w czym jesteśmy tacy jak inni, natomiast tożsamość jednostkowa wskazuje na naszą odrębność od innych"4. Tożsamość indywidualna

\footnotetext{
2 J. Brągiel, A. Kurcz, Pracownik socjalny. Wybrane problemy zawodu wokresie transformacji społecznej, Uniwersytet Opolski, Opole 2002, s. 146.

3 Elementarnepojęcia pedagogiki społecznej ipracysocjalnej, red. D. Lelak, T. Pilch, Wydawnictwo Akademickie „Żak”, Warszawa 1999, s. 310.

4 A. Giddens, Socjologia, PWN, Warszawa 2005 , s. 49.
} 
obejmuje te cechy, które przysługują wyłącznie danej jednostce, których z nikim nie dzieli, które tworzą jej niepowtarzalne, indywidualne ego. Są to swoiste właściwości ciała i umysłu: wygląd, uroda, dziedziczony i unikatowy kod genetyczny, osobowość będąca zapisem niepowtarzalnych doświadczeń życiowych, wiedza, jaką posiadamy, nasze poglądy, przekonania, wartości, jakie wyznajemy, to, w co wierzymy, to, czego się boimy i czym się cieszymy, kogo kochamy, a kogo nienawidzimy itp. ${ }^{5}$ Cechy te czynią nas wyjątkowymi w postrzeganiu samych siebie, a także wpływają na to, jak odbierają nas inni. Nie ma dwóch takich samych osób, każda jest w pewien sposób inna. Są jednak i takie cechy, które dzielimy z niektórymi ludźmi, a tym samym różnią nas one razem od innych ludzi. Dzięki cechom pośredniej natury, podobieństwom i różnicom cząstkowym wielość ludzi, populacja, dzieli się na liczne mniejsze całości, czyli strukturalizuje się wewnętrznie. Zbiór jednostek podobnych pod jakimś względem i różniących się pod tym względem od innych nazwiemy kategorią statystyczną. Natomiast zbiór ludzi podobnych pod względem cech społecznie doniosłych stanowi już coś więcej niż zbiór statystyczny. W odróżnieniu od kategorii statystycznej będziemy w tym przypadku mówić o kategorii socjologicznej, którą można obiektywnie wyodrębnić. Natomiast w sytuacji gdy sami członkowie danej zbiorowości zaczynają myśleć w kategoriach: „my”, „nasi”, „obcy”, mówimy o kategorii społecznej ${ }^{6}$, której nieodłącznym komponentem jest „tożsamość zbiorowa”. W definicji zaproponowanej przez Anne Llewellyn, Agu Lorraine oraz Davida Mercera: „Tożsamość społeczna przejawia się w przynależności do grup społecznych, w miejscu jednostek w układach społecznych. Tożsamość społeczna to także interakcje zachodzące pomiędzy jednostkami. Tożsamość społeczna może zarówno łączyć poszczególne jednostki, jak również separować jedne grupy od innych"7. To już nie jest wspólnota zdefiniowana przez zewnętrznych, obiektywnych obserwatorów, lecz przeżyta subiektywnie od wewnątrz przez samych członków zbiorowości. Mówi się wówczas o pojawieniu się subiektywnej więzi społecznej. Takie subiektywne poczucie wspólnoty, wytwarzanie się tożsamości zbiorowej może wyłaniać się i ewoluować stopniowo. W trakcie tego procesu wytwarza się swoisty

5 Por. P. Sztompka, Socjologia. Analiza społeczeństwa, Znak, Kraków 2002, s. 181.

6 Por. P. Sztompka, Socjologia. Analiza społeczeństwa, ZNAK, Kraków 2002, s. 185.

7 A. Llewellyn, L. Agu, D. Mercer, Sociology for social workers, Cambridge 2008, s. 47. 
kodeks honorowy, który wymaga specyficznego zachowania od ludzi o tej samej tożsamości zbiorowej.

Wyróżnić możemy skrajne koncepcje tożsamości zbiorowej, czyli:

- mocną koncepcję tożsamości, w której jest ona zobiektywizowana dla całej grupy. Poszczególne jednostki są nieświadome tej tożsamości. Koncepcja ta również zakłada, iż wszystkie grupy posiadają określoną tożsamość i nie są w stanie jej utracić;

- słabą koncepcję tożsamości - gdzie jest ona kategorią zbyt zmienną, by stanowić podstawę postaw i zachowań.

\section{Tożsamość społeczna w teorii konstruktywizmu społecznego}

W teorii konstruktywizmu społecznego przyjmowana jest opcja pośrednia pomiędzy powyżej opisanymi skrajnymi ujęciami. W ten sposób rozumiana tożsamość jest faktem interakcyjnym (subiektywnym i obiektywnym), kształtującym się, ale na tyle ontologicznie silnym, iż stanowi podstawę postaw i zachowań. Rzeczywistość obiektywna według Petera Bergera i Thomasa Luckmanna może być łatwo „przełożona” na rzeczywistość subiektywną i vice versa. Tożsamość po wykrystalizowaniu się jest podtrzymywana, modyfikowana, a nawet formowana na nowo przez stosunki społeczne. Te zaś są determinowane przez strukturę, procesy i kulturę (warstwę symboliczno-normatywną). Berger i Luckmann stwierdzają, iż teorie na temat tożsamości są zawsze osadzone w ogólniejszej interpretacji rzeczywistości, są „wbudowane w uniwersum symboliczne oraz jego teoretyczne uprawomocnienia i ulegają zmianie wraz z tymi uprawomocnieniami"'. Zatem każde teoretyzowanie na temat tożsamości, a także danych jej typów, musi mieć miejsce w ramach określonych interpretacji teoretycznych. Ważne jest również założenie konstruktywizmu społecznego, iż jednostka potrzebuje nie tylko potwierdzenia swej tożsamości implicite, co zapewniają jej codzienne kontakty z innymi, ale także potwierdzenia explicite o pewnym ładunku emocjonalnym. Najważniej-

$8 \quad$ P. Berger, T. Luckmann, Społeczne tworzenie rzeczywistości, Biblioteka Myśli Współczesnej, Warszawa 1983, s. 263. 
szym środkiem utrzymania faktów społecznych jest konwersja rozumiana jako komunikacja przez rozmowę. Ludzie rozmawiają ze sobą i poprzez ten właśnie aparat konwersacyjny nieustannie modyfikują rzeczywistość społeczną. Moment spotkania, wytwarzająca się struktura „pomiędzy” jest fundamentalna w rozważaniach teoretycznych na temat tożsamości społecznej. Wyłania się tutaj również pytanie o stopień autonomii i współbycia tworzących struktury społeczne. Każdy człowiek, chociaż nie jest pozbawiony wymiaru historycznego, jest przede wszystkim indywidualną egzystencją: „ma swoją historię, która nie jest jedynie rezultatem jego własnych wolnych czynów. Natomiast działania wewnętrzne są jego własnością i będą zawsze należały do niego; ani historia, ani historia powszechna nie może jednostki ich pozbawić, one towarzyszą jej ku radości lub ku strapieniu"9. Być jednostką to nie tylko być fragmentem jakiejś całości. Człowiek jest konkretną egzystencją - bycie jednostką jest wartością. Każdy człowiek jest nie tylko członkiem społeczeństwa, ponieważ najpierw i przede wszystkim jest niepowtarzalnym sobą. Aby możliwe było spotkanie, konieczna jest więc owa wspólna przestrzeń, „przestrzeń międzyludzka", mająca swoistą ontologię, jakby swoją strukturę, naznaczoną środkami kodów kulturowych.

\section{Pojęcie „nowej tożsamości” pracowników socjalnych - analiza trójwymiarowa}

W odniesieniu do dotychczasowych rozważań na temat tożsamości przeprowadzona zostanie analiza pracowników socjalnych w kontekście profesjonalizacji ich zawodu. Konieczność zaspokojenia rosnącego zapotrzebowania na pomoc społeczną, służbę medyczną i pracę socjalną, a także aspiracje Polski do członkostwa w Unii Europejskiej spowodowały, że na początku lat 9o. xx wieku zainicjowano proces licznych zmian w ramach polityki społecznej, wprowadzając wiele modyfikacji o charakterze prawno-organizacyjnym w systemie pomocy społecznej. Jednocześnie podkreślano rosnącą potrzebę profesjonalizacji pracy socjalnej, zakładając, że stanowi ona podstawę procesu przekształcania pracowników socjalnych

9 S. Kierkegaard, Albo-albo, t. II, PWN, Warszawa 1996, s. 234. 
jako grupy zawodowej i dostosowania jej do zachodzących przeobrażeń społecznych. Zmiany tożsamościowe tej grupy zawodowej stały się nieuniknione. Łącząc czasowość i dynamizm tożsamości z jej statycznym w pewnym wymiarze - przejawem, uzasadnione wydaje się wprowadzenie rozróżnienia na „starą" i „nową tożsamość” pracowników socjalnych. „Nowa tożsamość” aktualnie staje się, wyłania w sferze życia społecznego i w obszarze zagadnień teoretycznych, oznacza trwający obecnie proces, a nie artykulację nowej tożsamości zbiorowej.

Ilustracja 1. Trójwymiarowe ujęcie „nowej tożsamości” pracowników socjalnych

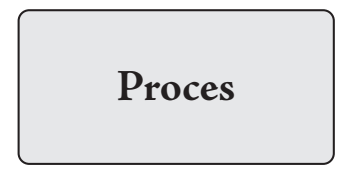

Struktura społeczna

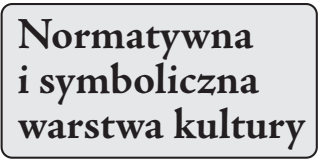

Działania profesjonalne pracowników socjalnych. Analizyः kodeksów etycznych, wyników badań.

Zewnętrzne instytucjonalne otoczenie profesji. Analizy: ustaw o pomocy społecznej.

Opinie klientów pracowników socjalnych.

Analizy: wyników badań empirycznych.

Źródło: koncepcja i opracowanie własne

„Nowa tożsamość” pracowników socjalnych jako fakt społeczny kształtowana jest przez trzy główne czynniki:

- procesy,

- strukturę społeczną,

- normatywną i symboliczną warstwę kultury.

Procesy kształtujące tożsamość pracowników przejawiają się w dynamicznym rozwoju profesjonalizacji, a szczególnie w tym jej fragmencie, który dotyczy kształtowania się etosu zawodowego i konkretnych działań podejmowanych przez pracowników socjalnych w tym zakresie. 
Struktura kształtująca tożsamość pracowników socjalnych to podłoże instytucjonalno-prawne. Natomiast symboliczna warstwa kultury jest ściśle związana $z$ budowaniem więzi społecznych. Przejawem tego wymiaru kształtującego tożsamość pracowników socjalnych będzie ich relacja z klientami. Ta relacja jest z gruntu etyczna - to spotkanie ze „słabszym”, potrzebującym pomocy.

\section{„Nowa tożsamość" pracowników socjalnych - kodeksualny wymiar analizy}

Pierwszy z wymiarów „nowej tożsamości” pracowników socjalnych stanowi wgląd w kształtujący się etos tej grupy zawodowej. Słowo to, podobnie jak „etyka”, pochodzi od greckiego ethos, oznaczającego charakter, dobre obyczaje i właściwe zachowanie.

Interesujące są tutaj przede wszystkim zachowania pracowników socjalnych w obliczu dylematów etycznych. Pracownicy socjalni i inni profesjonaliści w dziedzinie świadczeń ludzkich, codziennie stający wobec wyzwań natury etycznej, doskonale zdają sobie sprawę, że na ich etykę pracy wpływa wiele czynników: wyznawane wartości osobiste, normy społeczne i praktyki kulturowe, przepisy prawa oraz otoczenie. Wiele profesji, łącznie z pracą socjalną, opracowuje wskazówki mające służyć pomocą w ważeniu tych czynników i podejmowaniu decyzji etycznych. Kodeksy etyczne często stanowią pryzmat, przez który spogląda się na kwestie etyczne, a w przypadku pracowników socjalnych korzysta z nich w podejmowaniu codziennych decyzji dotyczących poszczególnych przypadków, w stosunkach z kolegami i przełożonymi oraz dla zrozumienia swojej odpowiedzialności wobec społeczeństwa. W oczywisty sposób każdy kodeks etyczny wypływa z wartości i przekonań ludzi, którzy go tworzą, i odzwierciedla aktualne postawy społeczne kultury, w której powstaje. Obecnie obowiązujący w Polsce kodeks etyczny pracowników socjalnych jest w dużej mierze kopią amerykańskiego kodeksu zaprezentowanego przez NASW w 1997, zrewidowanego w 2008 roku. 
Kodeks Etyczny Polskiego Towarzystwa Pracowników Socjalnych ma następującą strukturę:

Preambuła

Dział I. Ogólna postawa i sposób postępowania pracownika socjalnego

Dział II. Odpowiedzialność etyczna pracownika socjalnego wobec klienta

Dział III. Odpowiedzialność etyczna pracownika socjalnego wobec współpracowników

Dział Iv. Odpowiedzialność etyczna pracownika socjalnego wobec pracodawcy

Dział v. Odpowiedzialność etyczna pracownika socjalnego wobec społeczeństwa

Porównanie kodeksów NASw i polskiego wykazuje wiele podobieństw w kwestii podstawowych wartości i wskazań obowiązujących członków profesji. W obu na przykład podkreśla się rolę pracowników socjalnych w wywoływaniu i kształtowaniu zmian społecznych oraz ich zaangażowanie w dobro wspólne całego społeczeństwa. Świadczy o tym fragment preambuły polskiego kodeksu: „Potrzeba stworzenia Kodeksu Etycznego wynika ze świadomości, iż praca socjalna jest siłą napędową zmian społecznych, sumieniem społeczeństwa"10. Oba kodeksy, polski i amerykański, powołują się na sprawiedliwość społeczną. Podobieństwa obejmują także wskazówki odnoszące się do postaw osobistych, stosunku do klientów, interakcji z kolegami, postawy wobec przełożonych oraz obowiązków wobec społeczeństwa jako ogółu. Podobnie jak amerykański, tak polski kodeks nawiązuje do głównej idei pracy socjalnej: „Poszanowania godności człowieka i obrony tej godności, prawa człowieka do samostanowienia, dbałości o równość szans"11.

Chociaż kodeksy polski i amerykański wykazują wiele podobieństw, różnice między nimi mogą się ujawnić w sposobie ich stosowania przez praktyków pracy socjalnej.

W Polsce właściwie nie ma obowiązku stosowania się do tego kodeksu etycznego, brakuje jakichkolwiek prawnie uregulowanych sankcji, które miałyby stać na straży respektowania go. Samo istnienie tego dokumen-

10 Kodeks Etyczny Polskiego Towarzystwa Pracowników Socjalnych, Preambuła, s. 1.

11 Kodeks Etyczny Polskiego Towarzystwa Pracowników Socjalnych, Preambuła, s. 1. 
tu jest, w mojej opinii, niewystarczające do tego, aby był on prawidłowo interpretowany i stosowany w praktyce. Potwierdza to fakt, iż studenci pracy socjalnej, z którymi spotykam się podczas zajęć, a są to w większości osoby pracujące już w szeroko rozumianej pomocy społecznej, poznają kodeks dopiero na zajęciach uniwersyteckich - to znaczy, iż nigdy wcześniej nie stosowali go w sposób świadomy i zamierzony w relacjach ze swoimi klientami. Dylematy etyczne rozstrzygają w oparciu o własną intuicję, ewentualnie proszą o wsparcie kolegów po fachu.

Warto też zwrócić uwagę na fakt, że język obu kodeksów (polskiego i amerykańskiego) jest bardzo ogólny i odwołuje się do profesjonalnej oceny pracownika. W rezultacie w różnych krajach i różnych kręgach kulturowych, nawet w różnych regionach jednego kraju, pracownicy socjalni mogą różnie interpretować zawarte w nim wskazówki.

Kodeks Etyczny Polskiego Towarzystwa Pracowników Socjalnych w pełni przedstawia główne wartości pracy socjalnej, o czym jest mowa w pierwszym punkcie: „Pracownik socjalny zobowiązany jest do poszanowania godności klienta i jego prawa do samostanowienia"12. W dokumencie mówi się bezpośrednio o odpowiedzialności pracowników socjalnych - czyli tej wartości, która w najistotniejszy sposób konstytuuje „dobro klienta” - na wielu płaszczyznach ich działań profesjonalnych.

Teoretycy pracy socjalnej podkreślają, jak ważnym dokumentem jest kodeks etyczny w procesie kształtowania „nowej tożsamości” pracowników socjalnych; natomiast rozbieżności w jego interpretacji i rozmaite formy zastosowania przez pracowników socjalnych w konkretnych sytuacjach wskazują na specyfikę tego procesu profesjonalizacji w Polsce. Pracownicy socjalni nie w pełni zdają sobie sprawę, że etos zawodowy to kluczowy element procesu profesjonalizacji; ich opinie w tej kwestii są najczęściej zbyt powierzchowne i pełne sprzeczności. Wskazują na to wyniki najnowszych ogólnopolskich badań pracowników socjalnych ${ }^{13}$, z których wynika, że wiedzą oni, iż ich zawód nie cieszy się dużym prestiżem, ale etycznych aspektów profesji nie wymieniają jako elementów profesjonalizacji. Poproszeni o podanie przedsięwzięć, które mogłyby wpłynąć na wzrost prestiżu zawodu pracownika socjalnego, na pierwszym miejscu

12 Kodeks Etyczny Polskiego Towarzystwa Pracowników Socjalnych, Dział I, pkt 1.

13 Czy podejście aktywizujące ma szansę?, red. M. Rymsza, Raport IsP, Warszawa 2011, s. 114. 
wymienili podniesienie wynagrodzeń, na drugim - uznanie tej profesji za zawód zaufania publicznego, na trzecim - powołanie do życia samorządu zawodowego pracowników socjalnych. Na kolejnych miejscach znalazły się działania ułatwiające pracę (przydzielenie samochodu służbowego), podnoszące kwalifikacje (refundowanie kosztów studiów zawodowych) lub zwiększające autonomię pracownika socjalnego przez ograniczenie ingerencji administracji i radnych w jego decyzje zawodowe. Nie ma mowy o standardach etycznych jako odrębnym i kluczowym elemencie procesu profesjonalizacji. A przecież bez odwołania się do standardów etycznych nie można wyznaczać ścieżki profesjonalizacji, a już na pewno nie w przypadku zawodów opierających się na relacjach międzyludzkich.

Dokonując analizy kodeksu i jego wpływu na „nową tożsamość” pracowników socjalnych, można stwierdzić, że w Polsce nie ma obowiązku stosowania się do zasad etycznych zawartych w kodeksach, co rodzi paradoksy w trakcie procesu profesjonalizacji. Obserwujemy rozłam pomiędzy etycznymi wskazówkami postępowania zawartymi w kodeksie etycznym a zachowaniem pracowników socjalnych w relacjach z klientami. Polski kodeks etyczny nie jest znany w wystarczającym stopniu w środowisku pracowników socjalnych, a także studentów pracy socjalnej. Studenci i praktykujący pracownicy socjalni nie uświadamiają sobie, jak ważny jest kodeks etyczny w procesie profesjonalizacji i w wielu konkretnych sytuacjach, w których spotykają się z klientem twarzą w twarz i rozwiązują problemy. Bez specyficznego zbioru zasad etycznych nie możemy mówić o profesji, o profesjonalnym działaniu, szczególnie w tych obszarach zawodowych, w których centralnym elementem jest relacja z drugim człowiekiem - odbiorcą profesjonalnej usługi.

\section{Etyczny wgląd w „nową tożsamość” pracowników socjalnych w wymiarze strukturalnym}

Zakres pomocy udzielanej w ramach pracy socjalnej oraz zakres obowiązków pracowników socjalnych są ograniczone instytucjonalnie i opisane w specjalistycznych ustawach. Teoretyczne rzecz ujmując, normy określające formalno-prawny aspekt działania pracowników socjalnych powinny być skonstruowane tak, aby umożliwiały praktyczną realizację podstawo- 
wych zasad aksjologicznych pracy socjalnej, takich jak: odpowiedzialność, sprawiedliwość, zasada indywidualizacji, uznanie prawa klienta do samostanowienia, zasada poufności itd. Jednak w rzeczywistości może zaistnieć sytuacja, iż konieczność stosowania obowiązujących procedur formalnych utrudnia pracownikom socjalnym rozwijanie właściwej postawy wobec klientów, co w rezultacie osłabia ich wrażliwość na te aspekty kontaktu, które wykraczają poza granice zrutynizowanych działań. Należy także podkreślić fakt oparcia działalności wszystkich ośrodków pomocy społecznej - niezależnie od ich statusu - na tym samym, powszechnie obowiązującym akcie prawnym, który określa nie tylko katalog ich zadań, ale również wymogi dotyczące zasad zatrudnienia podstawowego personelu, czyli pracowników socjalnych, ich kwalifikacji oraz powinności zawodowych. To stanowi uzasadnienie do przyjęcia założenia, że osoby te będą wypełniały swoją podstawową misję, kierując się w stosunku do swoich klientów takimi samymi zasadami postępowania i stosując analogiczne strategie pomocowe. Potoczne doświadczenie uczy jednak, że konkretne działania podejmowane w ramach tych samych unormowań prawnych nie zawsze są jednakowe; bardzo wiele zależy od stanu świadomości ich realizatorów, poziomu ich profesjonalizmu i zaangażowania w pracę, a także od możliwości wykorzystania dostępnych na danym obszarze ogniw sieci pomocowej. Nie bez znaczenia jest także kontekst społeczny, w którym te działania są podejmowane.

Obecnie obowiązuje Ustawa o pomocy społecznej z 12 marca 2004 roku, która weszła w życie 1 kwietnia 2004 roku. Składa się z 161 artykułów (84 strony). Na początku wyrażona jest wprost zasadność konotacji pracy socjalnej z etyką: mianowicie jednym z wymienionych zadań pracy socjalnej jest „udzielanie pomocy zgodnie z zasadami etyki zawodowej”"14. Zawarte w niej przepisy sformułowane są w sposób umożliwiający ich zastosowanie do wielu indywidualnych i bardzo zróżnicowanych problemów konkretnych osób ubiegających się o pomoc: „Pomoc społeczna wspiera osoby i rodziny w wysiłkach zmierzających do zaspokojenia niezbędnych potrzeb i umożliwia im życie w warunkach odpowiadających godności człowieka"15. Jest to zdecydowanie pozytywna strona tej regulacji, ponie-

14 Ustawa z dnia 12 marca 2004 roku o pomocy społecznej, dział III, rozdz. 2, s. 65 (Dz.U. z 2015 roku, poz. 163, 693, 1045).

15 Ustawa z dnia 12 marca 2004 roku o pomocy społecznej, art. 2 , pkt 2. 
waż większa kategoryczność sformułowań mogłaby znacznie ograniczyć zakres jej stosowalności.

Istotne są te fragmenty ustawy, które wskazują na jej silny związek z zagadnieniami etycznymi i dostarczają wskazówek, jak rozwiązać konkretne dylematy etyczne. Przykładem jest kwestia dotycząca opieki nad dziećmi pozbawionymi opieki rodzicielskiej i zmiany w tym zakresie poczynione W 2011 roku. W ustawie czytamy: „Rodzina zastępcza w wypełnianiu swoich funkcji kieruje się dobrem przyjętego dziecka i poszanowaniem jego praw" ". Prawo dziecka do zapewnienia mu opieki w rodzinie zastępczej jest subsydiarne wobec jego prawa do życia w rodzinie. Priorytetową rolę rodziny naturalnej podkreśla również wzmianka w ustawie: „Udzielając pomocy, należy mieć na względzie podmiotowość dziecka i rodziny"17. Zgodnie z zasadą pomocniczości - podstawowa odpowiedzialność za kierowanie własnym życiem należy do osoby i jej najbliższego kręgu, tzn. do rodziny. Należy zatem udzielić rodzinie dysfunkcjonalnej wielowymiarowej pomocy zanim zapadnie decyzja o umieszczeniu dziecka w rodzinie zastępczej. Ustawa dokładnie określa zakres tej pomocy, a konieczność umieszczenia dziecka poza rodziną naturalną jest tu uznawana za wyjście ostateczne: „Rodzinie mającej trudności w wypełnianiu swoich zadań oraz dziecku z tej rodziny udziela się pomocy, w szczególności w formie:

- poradnictwa rodzinnego;

- terapii rodzinnej rozumianej jako działania psychologiczne, pedagogiczne i socjologiczne, mające na celu przywrócenie rodzinie zdolności do wypełniania jej zadań;

- pracy socjalnej;

- zapewnienia dzieciom opieki i wychowania poza rodziną"18.

Jednym z głównych zamierzeń reformy w 2011 było przygotowanie odpowiednio przeszkolonych rodzin zastępczych (w szczególności pełniących funkcję pogotowia rodzinnego, które ma zastąpić powszechnie krytykowaną instytucję pogotowia opiekuńczego) oraz ich wspieranie. Innym istotnym zamiarem była konieczność pełniejszej weryfikacji tzw. spokrewnionych rodzin zastępczych pod kątem tego, czy rzeczywiście sprostają potrzebom dziecka i będą oznaczały poprawę jego sytuacji ro-

16 Ustawa z dnia 12 marca 2004 roku o pomocy społecznej, art.72.

17 Ustawa z dnia 12 marca 2004 roku o pomocy społecznej, art. 19.

18 Ustawa z dnia 12 marca 2004 roku o pomocy społecznej, art. 70. 
dzinnej. O tym również jest mowa w ustawie: „Rodziny zastępcze uczestniczą w szkoleniu organizowanym przez powiatowe centrum pomocy rodzinie lub, na jego zlecenie, przez ośrodek adopcyjno-opiekuńczy lub inny podmiot. Zatwierdzenie lub odmowa zatwierdzenia programu szkolenia rodzin zastępczych następuje w drodze decyzji administracyjnej”19.

Ustawa określa, komu można przyznać status rodziców zastępczych: „Pełnienie funkcji rodziny zastępczej może być powierzone małżonkom lub osobie niepozostającej w związku małżeńskim, jeżeli osoby te spełniają następujące warunki:

- dają rękojmię należytego wykonywania zadań rodziny zastępczej;

- mają stałe miejsce zamieszkania na terytorium Rzeczypospolitej Polskiej;

- korzystają z pełni praw cywilnych i obywatelskich;

- nie są lub nie były pozbawione władzy rodzicielskiej, nie są ograniczone we władzy rodzicielskiej ani też władza rodzicielska nie została im zawieszona;

- wywiązują się z obowiązku łożenia na utrzymanie osoby najbliższej lub innej osoby, gdy ciąży na nich taki obowiązek z mocy prawa lub orzeczenia sądu;

- nie są chore na chorobę uniemożliwiającą właściwą opiekę nad dzieckiem, co zostało stwierdzone zaświadczeniem lekarskim;

- mają odpowiednie warunki mieszkaniowe oraz stałe źródło utrzymania;

- uzyskały pozytywną opinię ośrodka pomocy społecznej właściwego ze względu na miejsce zamieszkania"20.

Nieuchronność gruntownej reformy wynikała nie tylko z potrzeb ustawodawstwa wewnętrznego, lecz była też jednym z warunków zaakceptowania Polski w gronie państw Unii Europejskiej. Cała Ustawa o pomocy społecznej z 2004 roku powstała zgodnie z prawem unijnym.

Następnie ustawa określa postępowanie w razie niewywiązywania się rodziny zastępczej ze swoich obowiązków lub ustania warunków. Jeśli dotyczy to zawodowej niespokrewnionej z dzieckiem rodziny zastępczej, sta-

19 Ustawa z dnia 12 marca 2004 roku o pomocy społecznej, art. 77.

20 Ustawa z dnia 12 marca 2004 roku o pomocy społecznej, art. 73. 
rosta zawiadamia o tym sąd i może rozwiązać z tą rodziną umowę o pełnienie funkcji rodziny zastępczej bez zachowania terminu wypowiedzenia.

Twórcy reformy, zdając sobie sprawę z niemożliwości nagłych zmian, uznali, iż dawne domy dziecka nie powinny być likwidowane, lecz przekształcane w wielofunkcyjne ośrodki pomocy dziecku i rodzinie. Osobiście odbywałam praktyki w takiej instytucji (która właściwie powinna powoli znikać z puli ofert pomocy dzieciom pozbawionym opieki rodzicielskiej), ale w postaci zreformowanej. Nie był to olbrzymi budynek skupiający setki dzieci w różnym wieku, ale placówka mająca w sumie około pięćdziesięciu wychowanków. W domu tym panuje system „rodzinkowy”. Rodzinka składa się z około dziesięciorga dzieci w podobnym wieku. Rodzinka mieszka na jednym piętrze w odrębnym „mieszkanku”. W każdej rodzince są konkretni wychowawcy, którzy dobrze znają dzieci i nawiązują z nimi bliskie więzi. Dzieci zwracają się do nich „ciociu” lub „wujku”. Każde dziecko traktowane jest indywidualnie, wychowawcy omawiają z nim każdy problem, planują działania, ale przede wszystkim słuchają, co dziecko chce powiedzieć, przekazać.

Ustawa o pomocy społecznej ma zatem swoje praktyczne, a zarazem w pełni etyczne zastosowanie. Jej fragmenty dotyczące rodziny zastępczej są całkowicie zgodne z zasadami etycznymi współczesnej pracy socjalnej.

Należy jednak podkreślić, iż tylko w jednym jej fragmencie, w preambule, stwierdzono w sposób bezpośredni, jak ważne jest etyczne podłoże pracy socjalnej: jednym z zadań pracy socjalnej jest „udzielanie pomocy według zasad profesjonalnej etyki”. Choć Ustawa o pomocy społecznej stanowi bazowy dokument procesu profesjonalizacji pracowników socjalnych, nie wyjaśnia, czym są zasady profesjonalnej etyki, trudno też w niej odnaleźć odwołania do nich. W analizie przedstawiono te fragmenty regulacji, które niewątpliwe stanowią przykład zastosowania zasad etycznych w konkretnych sytuacjach pomocowych, ale brakuje w niej konkretnych wskazówek, konkretnych odwołań do zasad etycznych - trudno ją zatem w pełni wykorzystać w procesie profesjonalizacji, który musi być mocno osadzony w realiach profesjonalnego pomagania. Choć ustawa odpowiada na wiele aktualnych problemów, z jakimi boryka się pomoc społeczna, w zasadzie nie porusza kwestii samej pracy socjalnej. W dokumencie musimy sami poszukiwać, czasami nawet domyślać się, które artykuły dotyczą istotnych zmian w samej pracy socjalnej i które z tych postanowień 
w decydujący sposób wpływają na proces profesjonalizacji pracowników socjalnych. Odległym - aczkolwiek możliwym do osiągnięcia - celem jest powstanie Ustawy o pracy socjalnej, która dokładnie przedstawiałaby warunki instytucjonalno-prawne pracy socjalnej.

\section{Opiniotwórczy mechanizm powstawania „nowej tożsamości” pracowników socjalnych}

Od aktywności i kreatywności pracowników socjalnych w dużym stopniu zależy, jaki ich obraz utrwali się w świadomości klientów i w jaki sposób podejdą oni do oceny własnych potrzeb i sposobu rozwiązania nękających ich problemów. To trzeci wymiar analizy „nowej tożsamości” pracowników socjalnych. Właściwa, prawdziwa relacja pracowników socjalnych z klientami stała się źródłem i wyznacznikiem teorii współczesnej pracy socjalnej. Rzeczywistość jednak ukazuje niejednokrotnie zupełnie inne fakty, czego dobrym przykładem są wyniki badań klientów krakowskiego MOPS-u oraz ośrodków gminnych ${ }^{21}$.

Z badań tych wynika pewna sprzeczność - z jednej bowiem strony potwierdzają one szeroko rozpowszechnioną opinię, iż osoby znajdujące się w trudnej sytuacji życiowej, które decydują się na kontakt z placówkami pomocy społecznej, oczekują najczęściej pomocy pieniężnej. Większość respondentów (84,5\% w Krakowie i 88,9\% w gminach wiejskich) ujawniła, iż liczyła na uzyskanie takiej właśnie pomocy. Z drugiej strony żaden z nich nie zrezygnował z możliwości odbycia dłuższej rozmowy z pracownikiem socjalnym - a taką formę wsparcia zaproponowano co szóstemu respondentowi w Krakowie i co ósmemu mieszkającemu na wsi. Oznaczałoby to, iż wśród klientów istnieje realne, choć może nie zawsze jasno przez nich uświadomione, zapotrzebowanie na bliższy kontakt osobowy z profesjonalistą. Płynie stąd wniosek, iż w relacjach z klientami tę właśnie propozycję pomocową winni pracownicy socjalni eksponować szczególnie wyraźnie.

21 M. Bocheńska-Seweryn, K. Kluzowa, Działalność ośrodków pomocy społecznej w opiniach klientów, w: Problemy spoteczne, pomoc spoteczna, praca socjalna. Wymiarpolski i europej$s k i$, red. R. Majer, Częstochowa 2004, s. 13. 
Innym przykładem braku właściwej relacji pomiędzy pracownikami socjalnymi i ich klientami są badania dotyczące opinii mieszkańców Krakowa i powiatu krakowskiego na temat włóczęgostwa, które objęły 600 osób, z czego 462 ankietowanych stanowili mieszkańcy Krakowa, a 138 - mieszkańcy powiatu krakowskiego. Celem badań było ustalenie „mentalnej reprezentacji” zjawiska włóczęgostwa współcześnie i odpowiedź na pytanie, czy w opinii respondentów stanowi ono problem społeczny ${ }^{22}$. Szczególnie znamienne są fragmenty badań, które pokazują stosunek osób bezdomnych (w tym także włóczęgów) do pomocy udzielanej im w ramach pracy socjalnej. Jest to kolejny, bezpośredni obraz „nowej tożsamości” pracowników socjalnych, świadectwo tego, jak są oni postrzegani w dzisiejszym, ponowoczesnym świecie. Włóczędzy stanowią niewątpliwie specyficzną grupę pomocobiorców, wymagających specyficznego podejścia. Nie widzą potrzeby lub nie chcą aktywnie współpracować z pracownikami służb społecznych w celu zmiany swojej sytuacji życiowej. Dzieje się tak przede wszystkim dlatego, że w pewnym sensie, z takich czy innych względów, dają sobie przyzwolenie na taką egzystencję. To nie sprzyja nawiązywaniu pozytywnej współpracy i nie daje szans na trwałą zmianę, nawet jeśli podejmowane są działania pomocowe. Ludzie ci w większości nie zamierzają nic robić, by zmienić swoją sytuację. Opinie bezdomnych na temat oferowanej im pomocy były zwykle negatywne i wyrażały postawę roszczeniową: „Żadne schronisko nie przyjmuje na stałe osób, a nie zawsze jest takie schronisko w miejscu, gdzie człowiek mieszkał do tej pory, to niejako jest jakaś konieczność, pół roku tu może posiedzieć, pół roku tam, a z pracą też jest trudno" ${ }^{23}$ - powiedział jeden z respondentów. Bezdomni włóczędzy z reguły od kwietnia do września jeżdżą z miasta do miasta. Gdy jest ciepło, można spać praktycznie wszędzie, łatwiej też o pracę, zwłaszcza dorywczą. W okresie jesienno-zimowym, gdy rozpoczynają się chłodne dni i mrozy, przeczekują ten - jak mówią - „martwy sezon” w schronisku, noclegowni. Wybór kolejnego miejsca pobytu jest nierzadko przypadkowy, często jadą tam, gdzie pociąg ich zawiezie. Z tego wynika, że traktują oferowaną im pomoc bardzo doraźnie i mało poważnie. Nie ma ona w ich odczuciu doprowadzić do zmiany ich sytuacji życiowej, ale przeciwnie -

22 M. Nóżka, Włóczęgostwo. Zjawisko społeczne i interwencja społeczna, Uniwersytet Jagielloński Instytut Socjologii, Kraków 2006, s. 57.

23 M. Nóżka, Włóczęostwo. Zjawisko społeczne i interwencja społeczna, dz. cyt., s. 116. 
umożliwić przetrwanie w takiej właśnie sytuacji. Z reguły jeżdżą do dużych miast, gdyż tam łatwiej zdobyć środki do życia, są liczne jadłodajnie dla ubogich, schroniska i noclegownie. Niektórzy spośród respondentów twierdzili, że wielu Polaków za granicą żyje w środowisku osób bezdomnych. Polscy bezdomni żyjący niegdyś na zachodzie Europy chwalą lepsze warunki socjalne i pomoc. Są także zdania, że tam byli lepiej traktowani niż w Polsce. Niektórzy deklarują, że chcieliby tam wrócić, jeśli tylko by mogli. Przyjęcie Polski do Unii Europejskiej, a wraz z nim otwarcie granic innych państw dla Polaków, stworzyło możliwość emigracji tym, którzy szukają lepszej egzystencji. Niekoniecznie w poszukiwaniu pracy - także lepszych warunków życia na koszt pomocy społecznej. Na pytanie, czy będzie tam szukał pracy, respondent odpowiedział: „Po co? [...] Na zachodzie to najlepiej mieszkać na wagonach. Zajmowaliśmy cały wagon dla siebie, dla Polaków. Pilnowaliśmy tego wagonu. W Polsce żyję podobnie. Podoba mi się takie życie. Dopóki nie mam mieszkania, to tak. Do końca nie zamierzam mieszkać w noclegowni, czy gdzieś tam"24. Ta wypowiedź również wskazuje na stosunek osób bezdomnych do pomocy. Niektórzy respondenci twierdzili, iż w ogóle nie korzystają ze wsparcia ośrodków pomocy społecznej, ponieważ byłoby to dla nich upokarzające. Mówili, że niczego nie chcą i nie potrzebują jałmużny: „Nie lubię po opiekach chodzić, bo w opiekach ochłapy dają ludziom. Ja jestem samowystarczalny. Potrzebuję ubranie, to zawsze przyjdą ludzie, pomagają, jak mi coś potrzeba. Więcej przykrości od pracowników socjalnych niż od zwykłych ludzi"25. „Ja po furtach nigdy nie chodziłem [...]. Nie korzystam nigdy, z żadnej instytucji. Po co będę szedł i się poniżał. Dla mnie to poniżenie"26.

Jak wynika z przytoczonych wypowiedzi, niechęć do korzystania z pomocy społecznej bierze się z przekonania o własnej zaradności i niezależności, ale także z dostrzegania niechęci pracowników instytucji pomocowych wobec bezdomnych i upokorzenia, jakie wiąże się z korzystaniem z tego typu pomocy. Niektórzy twierdzą, że nie korzystają z pomocy społecznej, ponieważ ich sytuacja w domu rodzinnym jest zbyt dobra. $Z$ tego też względu nie zgadzają się na przeprowadzenie wywiadu środowiskowego. Kierując się wstydem lub ambicją, nie chcą, by ich rodzina dowiedziała

24 M. Nóżka, Wtóczęgostwo. Zjawisko społeczne i interwencja społeczna, dz. cyt., s. 122.

25 M. Nóżka, Wtóczęgostwo. Zjawisko społeczne i interwencja społeczna, dz. cyt., s. 122.

26 M. Nóżka, Włóczęgostwo. Zjawisko społeczne i interwencja społeczna, dz. cyt., s. 122. 
się o ich aktualnej sytuacji. Według większości respondentów pracownicy socjalni nie pomagają realnie potrzebującym. Ich zdaniem wszystko, co robi się w instytucjach pomocowych, to tylko pozory, a ludzie, którzy tam pracują, są obojętni na potrzeby bezdomnych. W niektórych opiniach pojawiają się zarzuty, że pracownicy pomocy społecznej zaspokajają tylko własne potrzeby; okradają bezdomnych, zabierając dla siebie ładniejsze rzeczy lub lepsze produkty z tzw. darów. Takie postrzeganie pomocy społecznej, dodatkowo przekazywane między sobą, powoduje, że bezdomni niechętnie korzystają z jej ofert, bowiem czują się lekceważeni i oszukiwani. Niektórzy spośród respondentów stwierdzili, że wymagaliby lepszych świadczeń, wyższych płac za swoją pracę, a od pracowników pomocy społecznej więcej poświęcenia, a nawet pracy 24 godziny na dobę. Nawet gdy jeden z rozmówców wypowiedział pozytywną opinię na temat pomocy oferowanej bezdomnym: „Gdyby takich domów nie było [schronisk, noclegowni], to w każdym mieście byłaby spalarnia zwłok, no bo wszyscy spaliby na działkach"27, to w dalszej części wypowiedzi bezwzględnie ją skrytykował: „W więzieniu kiedyś to wykańczali nas psychicznie, pokazywali w ten sposób, że jesteśmy nikim. Tak samo jak pokazują tutaj [w schronisku]" 28 . Respondenci mieli wiele krytycznych uwag co do charakteru świadczonej im pomocy. Sami przy tym nie wykazywali żadnej inicjatywy i aktywności w celu zmiany swojej sytuacji życiowej. Rozczarowani tym, co dostają, niezadowoleni z życia, które wiodą, charakteryzują się malkontenctwem i postawą roszczeniową. „Korzystałem z instytucji, ale większość to fikcja. To jest tylko opisywane do gazet. Na wigilię czy coś takiego, co to za dobroci na obiad [ironia w głosie]. Jakąś zupkę rzucić czy ziemniaczki. To nie jest obiad, trzy deko kiełbasy, dwie kromki chleba, to raczej nie jest kolacja. A w gazetach się opisuje, co to za dobrocie wychodzą z Mops-ów [...]. Każde stowarzyszenie robi sobie reklamę. Dla przekrętów, o kasę chodzi. Jest tylko pchanie pieniędzy w stowarzyszenia, nic więcej. Bezdomnym nigdy się nie poprawiło i się nie poprawi. To jest kwestia tylko reklamy i nic więcej”29. „Nie korzystam z innych instytucji. To jest kompletna bzdura. Te wszystkie MOPs-y. Oni dostają olbrzymie dotacje. Na co te pieniądze idą, to jest ich słodka tajemnica. Ja potrzebowałem mieć dalej pomoc lekarską.

27 M. Nóżka, Wtóczęgostwo. Zjawisko społeczne i interwencja społeczna, dz. cyt., s. 122

28 M. Nóżka, Włóczęgostwo. Zjawisko społeczne i interwencja społeczna, dz. cyt., s. 122.

29 M. Nóżka, Włóczęgostwo. Zjawisko społeczne i interwencja społeczna, dz. cyt., s. 144. 
Zwróciłem się do MOPS-u, czy jest szansa na pomoc finansową. W MOPSie powiedziano mi, że mogę dostać 50 zł. Powiedziałem tej pani, żeby sobie wzięła te 50 zł i wsadziła w buty, będzie wyższa i niech sobie zapłaci

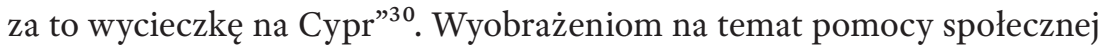
i określonym wobec niej oczekiwaniom towarzyszy przekonanie, że osoby pracujące w placówkach pomocowych czują względem bezdomnych niechęć, a nawet odrazę. Sprawia to, że bezdomni tym bardziej - jak twierdzą - unikają korzystania z oferowanego wsparcia: „U nas ludzie w opiekach pracują, co wstręt czują do ludzi bezdomnych. Jak się do jakiejś instytucji zgłoszę, to lekceważenie. A bezdomny [machnął ręką] - śmieć. Takie są relacje. Podstawowe prawa niech by były, no żeby mnie nie poniżano. My nie przedstawiamy dla nich żadnej wartości, rozumie pani? Żadnej wartości”31.

Próbę jakiejkolwiek zmiany dodatkowo komplikują i utrudniają zaktywizowane mechanizmy obronne, takie jak wyparcie, zaprzeczenie, przemieszczenie czy racjonalizacja, a także psychologiczne strategie adaptacyjne, które pozwalają im na takie postrzeganie i interpretowanie rzeczywistości, by mogli oni odnaleźć sens w tym, jak żyją i dlaczego tak żyją. Funkcją tych mechanizmów jest redukcja poziomu lęku i ochrona poczucia godności, która pozwala im utrzymać względnie pozytywną samoocenę.

Klienci uważają, że nawet jeżeli pracownicy socjalni spełniają ich żądania, to jest to zawsze za mało, ponieważ klienci muszą udowodnić, że nikt nie chce ani nie potrafi im pomóc. W relacje wchodzą tak, jakby była to gra sił, w której jest się albo stroną podległą, albo dominującą. Zależy im na tym, by dominować. Potwierdzeniem takiego stanu rzeczy są wyniki badań Instytutu Spraw Publicznych ${ }^{32}$. Pracownicy socjalni w badaniach podkreślali małe kompetencje społeczne i kulturowe swoich klientów, nieporadność życiową oraz kultywowany od pokoleń styl życia „z pomocy społecznej”. Klienci w tych wypowiedziach jawili się często jako osoby wrogie, roszczeniowe, zagrażające zdrowiu i życiu pracownika ${ }^{33}$.

30 M. Nóżka, Włóczęgostwo. Zjawisko społeczne i interwencja społeczna, dz. cyt., s. 144.

31 M. Nóżka, Wtóczegostwo. Zjawisko społeczne i interwencja społeczna, dz. cyt., s. 144.

32 Pracownicy socjalni: pomiędzy instytucja pomocy społecznej a środowiskiem lokalnym. Raport ISP, red. M. Dudkiewicz Warszawa 2011, s. 37.

33 Pracownicy socjalni: pomiędzy instytucją pomocy społecznej a środowiskiem lokalnym. Raport ISP, dz. cyt., s. 37 . 
Z zaprezentowanych badań wyraźnie wynika, iż relacyjna praca socjalna w obszarze bezdomności funkcjonuje w stopniu zalążkowym, a sam kontakt z pracownikiem socjalnym jest przez klientów pomocy społecznej oceniany raczej negatywnie.

\section{Myśląc aplikacyjnie}

„Nowa tożsamość" pracowników socjalnych w jej etycznym (co wynika z samej istoty pracy socjalnej) aspekcie została poddana analizie jako fakt społeczny w trzech wymiarach: proces (profesjonalne działania pracowników socjalnych, zwłaszcza w obliczu dylematów etycznych), struktura (otoczenie instytucjonalno-prawne profesji) oraz wymiar symboliczno-normatywny (relacja pracownik socjalny-klient, której najistotniejszym elementem jest opinia odbiorców pomocy na temat profesjonalistów od pomagania). Założono, iż proces profesjonalizacji jest niezwykle złożony, zaś ważnym, ale zarazem najmniej zbadanym jego wymiarem jest etos zawodowy.

Po rozpatrzeniu trzech wymiarów procesu profesjonalizacji pracowników socjalnych udowodniono, iż związek teorii z praktyką w polskiej pracy socjalnej jest ciągle niewystarczający. Pracownicy socjalni mają swój kodeks etyczny, ale nie respektują go w wystarczającym stopniu, nie uświadamiają sobie jego znaczenia, a nawet w wielu przypadkach w ogóle go nie znają. Ten stan rzeczy implikuje bierną postawę pracowników socjalnych wobec potrzeby stworzenia nowego, obszerniejszego kodeksu etycznego, nie mówiąc już o konieczności szukania źródeł etycznych wskazówek zawartych w tym dokumencie. Analiza otoczenia instytucjonalno-prawnego pracy socjalnej, które regulowane jest przez Ustawę o pomocy społecznej, pokazuje, iż tylko znikome jej fragmenty związane są z etycznym wymiarem procesu profesjonalizacji. Patrząc zaś na obraz pracowników socjalnych z perspektywy klientów, widzimy rzeczywistość pełną wad i niedociągnięć.

Zatem proces profesjonalizacji pracy socjalnej i jego główny efekt powstawanie „nowej tożsamości” pracowników socjalnych - jawi się jako fakt społeczny z wieloma wewnętrznymi sprzecznościami. Można zaryzykować stwierdzenie, że gdyby pracownicy socjalni stosowali się 
do wskazówek etycznych, rozumieli je i kierowali się nimi przy wyborze ścieżki zawodowej, proces profesjonalizacji pracy socjalnej w Polsce można by uznać za bardzo efektywny. Jednak w rzeczywistości jest on w dużym stopniu niejednoznaczny, a nawet sprzeczny w swych manifestacjach. W każdym z opisanych trzech wymiarów „nowa tożsamość” pracowników socjalnych jako fakt społeczny istnieje „nie w pełni”, zawiera sprzeczności, których rozwiązanie wewnątrz tego faktu wydaje się być przyszłością. Pomimo wielu negatywnych sytuacji niewątpliwie cennym obecnie środowiskiem rozwoju profesjonalnej pracy socjalnej w Polsce jest środowisko pracowników socjalnych zatrudnionych w placówkach specjalistycznych, szczególnie w szpitalach. Ta grupa pracowników prezentuje zdecydowanie wyższy poziom samooceny, podkreśla znaczenie samorealizacji i kwalifikacji obok doświadczenia zawodowego, wskazuje na wysoki poziom efektywności podejmowanych działań, deklaruje satysfakcję i zadowolenie z pracy, a także dostrzega większy prestiż zawodu. $Z$ badań wynika ${ }^{34}$, iż respondenci z tej grupy zdecydowanie częściej deklarowali świadome wybranie zawodu pracownika socjalnego niż pracownicy zatrudnieni w miejskim ośrodku pomocy społecznej, którzy niezwykle często mówili w tym kontekście o przypadku. Pracownicy socjalni z placówek specjalistycznych znacznie częściej twierdzili również, że raz jeszcze wybraliby ten sam zawód, co jest niewątpliwie konsekwencją świadomych i przemyślanych decyzji. W większości realizują się oni poprzez pracę w zawodzie. Bardzo często traktują ją jako swego rodzaju misję, której spełnianie pozwala osiągnąć niezwykle ważną w tym zawodzie satysfakcję z pracy i pomocy innym, a także umożliwia poszerzenie zakresu wiedzy i świadomości społecznej nie tylko jako pracownika, ale przede wszystkim jako człowieka wrażliwego na krzywdę innych. Respondenci z tej grupy badanych praktycznie w równej mierze stawiają w pracy na doświadczenie zawodowe i kwalifikacje jako elementy konieczne w procesie udzielania profesjonalnej pomocy społecznej. Zdolności pozwalające na właściwe zdiagnozowanie i dostosowanie działań do problemu każdego klienta stanowią więc podstawę funkcjonowania pracowników w placówkach specjalistycznych. Profesjonalne nastawienie do klientów, innych pracowników, a także specjalistów korzystnie wpływa na rozwiązywanie

34 Czy podejście aktywizujące ma szansę?, red. M. Rymsza, Raport IsP, Warszawa 2011. 
problemów i udzielanie pomocy społecznej na wysokim poziomie. Dodatkowo satysfakcja $\mathrm{z}$ wykonywanych obowiązków i bardzo pozytywna subiektywna ocena efektywności własnych działań świadczy o wysokim poziomie świadomości zawodowej oraz wiedzy na temat podejmowanych inicjatyw i stosowanych form świadczenia pomocy. Uświadomienie sobie własnych kompetencji, predyspozycji, zdolności, a także ewentualnych braków jest niezwykle istotne dla procesu samorealizacji, podnoszenia kompetencji i podejmowania nowatorskich inicjatyw i rozwiązań. Kierunek działań podejmowanych przez pracowników placówek specjalistycznych wydaje się być kierunkiem przyszłości. Pracownik socjalny powinien być samodzielny, dbać o swoją autonomię, podejmować decyzje w oparciu o posiadaną profesjonalną wiedzę, a nie tylko przepisy i doświadczenie życiowe; powinien też generować nową wiedzę i inspirować nowe formy działania, aktywizować osoby potrzebujące i dążyć do osiągnięcia założonego celu.

Proces powstawania „nowej tożsamości” pracowników socjalnych jest najogólniejszym, powolnym, często karykaturalnym, a zarazem najbardziej pozytywnym aspektem zmian zachodzących w obszarze pracy socjalnej. Zawód pracownika socjalnego jest zawodem niezwykle złożonym. Praca $\mathrm{z}$ drugim człowiekiem, zrozumienie jego problemów i udzielenie mu właściwego, profesjonalnego wsparcia stanowi sens pracy w tym zawodzie i pozwala na identyfikację z nim we właściwym wymiarze.

\section{Abstrakt}

\section{Tożsamość społeczna jako fakt interakcyjny}

Głównym celem artykułu jest analiza etycznego, relacyjnego aspektu tożsamości społecznej. Zgodnie z teorią konstruktywizmu społecznego tożsamość jest faktem interaktywnym, nieustannie interpretowanym - powstającym i realizowanym poprzez interakcje i interpretacje społeczne. Jako fakt społeczny tożsamość kształtują trzy główne czynniki: proces, struktura, społeczna oraz normatywne i symboliczne warstwy kultury. Te trzy wymiary zostały poddane analizie na przykładzie „nowej tożsamości pracowników socjalnych” w Polsce, gdzie proces profesjonalizacji 
pracy socjalnej jest niezwykle dynamiczny i stanowi interesujący obszar do analiz kształtującej się tożsamości społecznej.

Słowa kluczowe: tożsamość społeczna, konstruktywizm społeczny, proces profesjonalizacji, praca socjalna

\section{Abstract}

Social identity as an interactive fact

The main purpose of this study is to analyze the ethical, relational aspect of social identity. According to theory of Social Constructionism, identity is an interactive fact continually interpreted - resulting from and realized through interactions and interpretations. It also seems to be a fact never consummated, always in process, looking for its place in the social world. As a social fact, identity is shaped by three main factors: processes, social structure, normative and symbolic layers of culture. These three dimensions are analyzed in the study on example of "new identity of social workers" in Poland - as an initial definition of ongoing process into social work.

Keywords: social identity, social identity of social workers, social constructivism, social process, micro and macro structure, ethics of social work

\section{Bibliografia}

Berger P., Luckmann T., Społeczne tworzenie rzeczywistości, Biblioteka Myśli Współczesnej, Warszawa 1983.

Bocheńska-Seweryn M., Kluzowa K., Działalność ośrodków pomocy społecznej $w$ opiniach klientów, w: Problemy społeczne, pomoc społeczna, praca socjalna. Wymiar polski i europejski, red. R. Majer, Częstochowa 2004.

Brągiel J., Kurcz A., Pracownik socjalny. Wybrane problemy zawodu w okresie transformacji spotecznej, Uniwersytet Opolski, Opole 2002. 
Czy podejście aktywizujące ma szansę?, red. M. Rymsza, Raport IsP, Warszawa 2011.

Elementarne pojęcia pedagogiki społecznej i pracy socjalnej, red. D. Lelak, T. Pilch, Wydawnictwo Akademickie „Żak”, Warszawa 1999.

Giddens A., Socjologia, PWn, Warszawa 2005.

Kierkegaard S., Albo-albo, t. II, PWN, Warszawa 1996.

Kodeks Etyczny Polskiego Towarzystwa Pracowników Socjalnych.

Llewellyn A., Agu L., Mercer D., Sociology for social workers, Cambridge 2008.

Nóżka M., Włóczęgostwo. Zjawisko społeczne i interwencja społeczna, Uniwersytet Jagielloński Instytut Socjologii, Kraków 2006.

Sztompka P., Socjologia. Analiza społeczeństwa, zNAK, Kraków 2002.

Ustawa z dnia 12 marca 2004 roku o pomocy społecznej. 